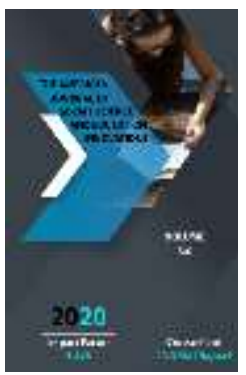

\title{
The Role And Advantages Of Distance Courses In The Innovative Educational System
}

\author{
Vohid Tojimamatovich Jo'rayev \\ Teacher Of Chair Of Applied Mathematics And Informatics, Fergana State University, \\ Uzbekistan
}

Journal Website:

http://usajournalshub.c

om/index,php/tajssei

Copyright: Original

content from this work

may be used under the

terms of the creative

commons attributes

4.0 licence.

\section{ABSTRACT}

The article focuses on the specifics of an open online course, which is one of the ways to continue the education of pupils and students in today's pandemic, which includes the technologies and types of distance learning. suspended. It is also thought that the changes caused by the pandemic and new solutions in education will bring the necessary innovative changes to the industry. Continuing the education of pupils and students in the article of a pandemic is a global problem today. The pandemic led to the closure of all educational institutions around the world, preventing students from learning. In this article, there is a problem of pupils and students. With the advent of distance education in the modern educational space, there have been significant changes in the education system. The article is devoted to the peculiarities of distance education, focusing on the technologies and types of distance education. The article is devoted to the analysis of public open online courses, the features of the creation and implementation of public open online courses in the educational process of a modern university. It is also thought that the changes caused by the pandemic and new solutions in education will bring the necessary innovative changes to the industry. These changes have undoubtedly brought about positive aspects of education in a certain order. The advantages of distance education are better organization of the learning process, ease and mobility of teaching, the implementation of professional and personal goals of the teacher, as well as increasing the efficiency of resource use. The materials presented and conclusions may be useful in discussing models for incorporating public open online courses into the university curriculum.

\section{KEYWORDS}

Distance education, mixed education, public open online courses, e-education, educational technologies, public education, globalization of education. 


\section{INTRODUCTION}

Distance educational courses or MOOC (Massive Open Online Courses) are one of the most important and controversial events of the last decade. While proponents of mass courses talk about a revolution in education, opponents cite evidence of low efficiency and the negative process of simplifying education. However, most members of the scientific community have no idea about ways to further develop mass courses in education. Nevertheless, many leading universities today are engaged in the creation and development of MOOC, indicating that public courses have a certain demand.

The purpose of this article is to consider distance education as part of the modern educational process in higher education and to highlight its positive aspects.

An article on the impact of the coronavirus on the education system has been published on the website of the World Economic Forum. According to him, the changes caused by the pandemic and new solutions in education can bring the necessary innovations to the industry.

But when the digital divide is taken into account, new approaches to education will increase inequality.

The main part of the article. At a time when the coronavirus is spreading rapidly across Asia, Europe, the Middle East and the United States, countries have taken drastic operational measures to reduce the spread of the pandemic. There have been a number of recent reports of school and university dropouts.

These changes have undoubtedly caused some inconvenience. But the pandemic has led to new innovations in education. While it is too early to talk about how COVID-19 will affect the education system around the world, it is important for innovation and digitalization in the long run. [9]

We have already talked in detail about the contingent of people who do not succeed in the traditional education system in ordinary life, who need educational services $[5,220-$ 225]. These include:

- Persons of different ages living in remote and inaccessible areas of the country, where higher education institutions are far away;

- People wishing to acquire new knowledge or secondary education;

- A wide contingent of users of educational services preparing for admission to higher education institutions;

- A contingent that does not have sufficient access to educational services due to limited access to traditional education, inability to combine education with work, and the presence of other special individuals (athletes, guards, immigrants, etc.);

- Servicemen of the Armed Forces of Uzbekistan and their families;

- Persons in need of inpatient education, but medically limited (disabled, hospitalized, have children under 3 years, need home education, etc.);

- A team of managers, teachers and other professionals at various levels in need of retraining and advanced training;

- Persons wishing to study in foreign educational institutions; 
- Persons duly registered, dismissed and laid off in employment services;

- Foreign citizens who for various reasons did not have the opportunity to study in Uzbekistan, but expressed a desire to study;

- The population in the context of a possible epidemic in the country and a pandemic that is a problem in the world today.

The above evidence suggests that in such a situation, it is necessary for the community to use forms of education through distance education courses that do not contradict the existing education system. [1, 30-45].

Distance education can be divided into television broadcasts, cloud-based online learning, WhatsApp, telegram or e-mail lessons, internet conferences, audio conferences, video conferencing, forums, webinars, blended learning. Among them, open online courses (public open online courses) are distinguished by the courses and opportunities they offer.

An open online course is a global experience in the field of education that is constantly evolving and does not have proven technologies.

The emergence of an open online course opens a new phase of educational services for universities. The term Massive Online Open Course was first used in 2008 by Dave Kormier to describe George Siemens 'Connectivism and Connective Knowledge distance education course.

An open online course is a distance education course for a large number of students who are far from each other, in which the content of all classes is public property, so students can access the materials without any restrictions. $[6,20]$

An open online course is first and foremost a course. There is a course when to start and end dates, lectures and assignments, students and teachers. But an open online course is different from traditional and full-time courses. Since the number of participants in the course exceeds several thousand, it means that it is necessary to automate the processes that the teacher initially performs during the lesson.

The amount of knowledge imparted reduces the value of the total volume for each person because the person's ability to assimilate that knowledge is limited. Due to this limitation, a person will have to choose what to study. Therefore, it is not enough for people to use information sources to successfully acquire knowledge, it is very important to see the interrelationship between these knowledges. The globalization of education also requires its own rules, so, there is a need for knowledge to be presented on a global scale in modern society. $[6,20]$

Various perspectives, its advantages and disadvantages have been explored to create an open online course. In this article, we will focus on its advantages.

From the point of view of teachers, the advantages of an open online course were found to be better organization of the learning process, ease and mobility of teaching, realization of professional and personal goals of the teacher, as well as increasing efficiency of resource use.[9]

Popular open online courses first appeared in the U.S. and then in Europe. 
As a result of the research, among the scientific publications of YM Roshchina, SY Roshchin, VN Rudakov published in 2018, there is information that fully meets our views [10]. It details their views on the strengths and weaknesses of an open online course during a survey of teachers and students. Of the remaining articles, only articles describing their own experiences in creating or using open online courses by teachers or administrators 'experiences working with such teachers were considered. Thus, the advantages of open online courses for teachers are:

- Participation in the development of an open online course is an image movement, so in the eyes of the world scientific community, the rise of the university is a priority;

- Public open online courses are a "bridge" connecting the university to the outside world. Because the number of participating students reaches several thousand;

- The university, which develops the image of a developed and prestigious educational institution through mass courses, will have an advantage in attracting potential students;

- In the opinion of teachers, an open online course contributes to the flexibility of knowledge acquired in various forms;

- Improves the quality of the open online course itself and the feedback of traditional course students based on it;

- The possibility of teaching in an individual case, the use of modern methods and materials [10, 183-184];

- The systematic work of part-time students is organized in the intersessional period [2, 125];
- Helps to understand the potential of students and develop their professional and personal qualities [8, 45];

- Provision of materials for independent work of students, automatic or mutual assessment of student work is achieved [4, 237];

- Strengthening the support of tutors by combining the subjects taught at the university with an open online course by advanced teachers, serves to understand the problems of targeted education [7, 237];

- Advertising opportunities (promotion of the open online course itself and the university that created the online course, advertising of other courses taught by the author);

- Experience in the form of new education (research and experiments with innovative pedagogical approaches, the opportunity to gain teaching experience in a wide and diverse audience);

- The ability to realize the personal intentions of the teacher (work on your reputation, the opportunity to launch an open online course of your first colleagues, fill in the list of achievements, make new contacts);

- Opportunity to share their knowledge and experience (contribute to open learning, increase public awareness of their topics);

- Development of research potential of new forms of education (open online course provides access to the majority of those involved in the course, which can be used as an experimental platform, for example, for new teaching methods or sociological, pedagogical and another research); 
- Financial incentives (universities provide incentives for teachers to develop online courses);

- Professional growth and development;

- Gaining new competencies by online course authors. [3, 398]

\section{CONCLUSION}

In short, a pandemic is an opportunity for students to learn the skills they need in a world where it is difficult to predict.

In such a situation, sound solutions, creative solutions, and possibly flexibility are important. These skills have also led to flexibility in the education system, which should be a priority for all students, and the development of information technology has led the academic community to seek new forms of teaching. This allows content to be delivered globally, not just to a single institution. This open online course was the main reason for the emergence of educational technology that could be read by tens of thousands of people.

The development of an open online course has many positive aspects for the university, ranging from filling a new position in the education market to new technologies in teaching and research.

\section{REFERENCES}

1. Abduqodirov A., A.Pardaev. Masofali o'qitish nazariyasi va amaliyoti. Toshkent, Fan, 2009.

2. Vaganova N.V., Telegina O.V. Integratsiya massovih otkritix onlaynkursov (MOOK) $v$ protsess obucheniya angliyskomu yaziku studentov zaochnogo otdeleniya // Teoriya i metodika obucheniya i vospitaniya $\quad v \quad$ sovremennom obrazovatelnom prostranstve: sb. materialov II Mejdunar. nauch.-prakt. konf. Novosibirsk: Izd-vo TsRNS. 2017. S. 123-128.;

3. Elizareva Yu.A. Sovremenno'y prepodavatel $\quad \mathrm{v}$ protsesse «MOOKizatsii» obrazovaniya // Gumanitarnaya informatika. № 10. 2016. -S. 92-100.

4. Juk L.G. Inoyazichnie massovie otkritie onlayn-kursi kak odin iz vidov vneauditornoy samostoyatelnoy raboti studentov // Voprosi metodiki prepodavaniya v vuze. № 5(19-1). 2016. - S. 235-243.

5. Jo'raev V.T. Ta'lim jarayonida masofaviy o'qitish kurslarining afzalliklari. - NamDU ilmiy axborotnomasi, 2019. - S. 220-225.

6. Mazurov A.Yu. Massovie otkritie onlayn-kursi v kontekste sovremennogo obrazovatelnogo protsessa v sfere visshego obrazovaniya. // Otkritoe i distantsionnoe obrazovanie. Moskva, 2015. №1. - S. 24

7. Mojaeva G. V. MOOCv izuchenii i prepodavanii istorii: $\mathrm{k}$ vo-prosu $\mathrm{o}$ vozmojnostyax i perspektivax // Istoricheskie issledovaniya $v$ tsifrovuyu epoxu: informatsionnie resursi, metodi, texnologii: materiali XV Mejdunar. konf. assotsiatsii «Istoriya i kompyuter» 2016. -S. 237-238.

8. Mojey K.A., Lukyanov D.V. Aspekti prakticheskoy realizatsii massovix otkritix onlayn-kursov $v$ obrazovatelnom protsesse visshego uchebnogo zavedeniya // Aktualnie problemi gumanitarnogo 
obrazovaniya: materiali IV Mejdunar. nauch.-prakt. konf. 2017. - S. 41-45.

9. Noraziah ChePa, Norida Muhd Darus. Development of An Improved Practicum Assessment Instrument for IT Programme from Industry's Perspective

http://sersc.org/journals/index.php/IJA ST/article/view/17035/8643

10. Rohina Ya. M., Rohin S. Yu., Rudakov V. N. Spros na massovie otkritie onlaynkursi (MOOC) opit rossiyskogo obrazovaniya // Voprosi obrazovaniya/Educational Studies. № 1. 2018. - S. 174-199.

11. Saripudin S, S.Sumarto, E.A.Juanda, Ade Gafar Abdullah and D.Rohendi. Didactic Model of Information and Communication Technology Literacy of Vocational Teachers http://sersc.org/journals/index.php/IJA ST/article/view/18795/9534 